\title{
Effects of replacing soybean meal with canola meal differing in rumen-undegradable protein content on ruminal fermentation and gas production kinetics using 2 in vitro systems
}

\author{
E. M. Paula, ${ }^{*}$ H. F. Monteiro, ${ }^{*} †$ L. G. Silva, ${ }^{*}$ P. D. B. Benedeti, ${ }^{\star} \ddagger$ J. L. P. Daniel,† T. Shenkoru, ${ }^{*}$ G. A. Broderick, $\S$ \\ and A. P. Faciola*1 \\ *Department of Agriculture, Nutrition, and Veterinary Sciences, University of Nevada, Reno 89557 \\ †Department of Animal Sciences, State University of Maringa, Maringa, Paraná, Brazil 87020-900 \\ łDepartment of Animal Sciences, Federal University of Viçosa, Viçosa, Minas Gerais, Brazil, 36570-000 \\ §Broderick Nutrition and Research LLC, Madison, WI 53705
}

\begin{abstract}
Previous research indicated that there were significant differences in rumen-undegradable protein (RUP) among canola meals (CM), which could influence the nutritional value of CM. The objectives of this study were to (1) evaluate the effects of feeding CM with different RUP contents on ruminal fermentation, nutrient digestion, and microbial growth using a dual-flow continuous culture system (experiment 1) and (2) evaluate ruminal gas production kinetics, in vitro organic matter $(\mathrm{OM})$ digestibility, and methane $\left(\mathrm{CH}_{4}\right)$ production of soybean meal (SBM) and CM with low or high RUP in the diet or as a sole ingredient using a gas production system (experiments 2 and 3 ). In experiment 1 , diets were randomly assigned to 6 fermentors in a replicated $3 \times 3$ Latin square. The only ingredient that differed among diets was the protein supplement. The treatments were (1) solvent-extracted SBM, (2) low-RUP solvent-extracted CM (38\% RUP as a percentage of crude protein), and (3) high-RUP solvent-extracted CM (50\% RUP). Diets were prepared as 3 concentrate mixtures that were combined with $25 \%$ orchardgrass hay and $15 \%$ wheat straw (dry matter basis). Experiments 2 and 3 had the same design with 24 bottles incubated 3 times for $48 \mathrm{~h}$ each. During the 48 -h incubation, the cumulative pressure was recorded to determine gas production kinetics, in vitro $\mathrm{OM}$ digestibility, and $\mathrm{CH}_{4}$ production. In experiment $1, \mathrm{~N}$ flow $(\mathrm{g} / \mathrm{d})$, efficiency of $\mathrm{N}$ use, efficiency of bacterial $\mathrm{N}$ synthesis, total volatile fatty acids $(\mathrm{m} M)$, and molar proportion of acetate, propionate, and isobutyrate were not affected by treatments. There were tendencies for a decrease in ruminal $\mathrm{NH}_{3}-\mathrm{N}$ and an increase in molar proportion of butyrate for the SBM diet compared with both $\mathrm{CM}$ diets. The
\end{abstract}

Received November 13, 2016.

Accepted March 10, 2017.

${ }^{1}$ Corresponding author: afaciola@cabnr.unr.edu molar proportion of valerate was greater in both $\mathrm{CM}$ diets, whereas the molar proportion of isovalerate and total branched-chain volatile fatty acids was lower for the CM diets compared with the SBM diet. In experiments 2 and 3, the SBM diet had a greater gas pool size than both CM diets. The SBM diet increased in vitro OM digestibility; however, it also tended to increase $\mathrm{CH}_{4}$ production ( $\mathrm{m} M$ and $\mathrm{g} / \mathrm{kg}$ of $\mathrm{DM}$ ) compared with both CM diets. Based on the results of this study, CM with RUP varying from 38 to $50 \%$ of crude protein does not affect ruminal fermentation, nutrient digestion, and microbial growth when CM is included at up to $34 \%$ of the diet.

Key words: ammonia nitrogen, rumen-degradable protein, rumen nitrogen metabolism, volatile fatty acid

\section{INTRODUCTION}

Canola meal $(\mathbf{C M})$ and soybean meal $(\mathbf{S B M})$ are common protein supplements fed to dairy cows in North America. Canadian solvent-extracted CM varies in nutritional composition because of environmental conditions during growth and harvest as well as cultivar variation and meal processing (Canola Meal Feeding Guide, 2015). We have shown in a survey including CM samples collected from 12 Canadian processing plants over $4 \mathrm{yr}$ that $\mathrm{CM}$ varies in RUP content, ranging from 43 to $51 \%$ of its CP (Broderick et al., 2016), which may have an effect on ruminal $\mathrm{N}$ metabolism and postruminal $\mathrm{N}$ utilization.

Recent studies comparing CM with SBM have shown an increase in milk yield and milk protein yield and a decrease in MUN with CM as the major source of protein (Martineau et al., 2013). Furthermore, CM reduced ruminal ammonia nitrogen $\left(\mathrm{NH}_{3}-\mathrm{N}\right)$ and branchedchain VFA (BCVFA) concentrations and decreased methane $\left(\mathrm{CH}_{4}\right)$ emissions per kilogram of ECM (Broderick et al., 2015; Gidlund et al., 2015). The reasons why CM improves milk and milk protein production, 
reduces MUN, and improves overall $\mathrm{N}$ utilization when replacing SBM are not clear. A better AA profile may play a role, but it is unclear whether a ruminal effect of feeding $\mathrm{CM}$ also plays a role in making $\mathrm{CM}$ a better protein supplement for dairy cows.

We know of no published studies reporting the effects of CM containing different RUP concentrations on rumen metabolism and gas production. Therefore, we selected from a subset of our previous survey study (Broderick et al., 2016) CM with the lowest (38\%; LCM) and greatest (50\%; HCM) RUP contents to assess whether this difference would affect ruminal $\mathrm{N}$ utilization. We also used a standard SBM source to serve as a control. We hypothesized that (1) CM with greater RUP content would increase RUP-N flow and decrease gas production compared with regular $\mathrm{CM}$ and (2) both CM diets would change ruminal fermentation, $\mathrm{N}$ metabolism, and total gas production compared with the SBM diet. Therefore, the objectives of this study were to evaluate the effects of feeding CM with different RUP concentration and SBM on (1) nutrient digestion, ruminal fermentation, $\mathrm{N}$ metabolism, and microbial protein synthesis using a dual-flow continuous culture system and (2) ruminal gas production kinetics, in vitro $\mathrm{OM}$ digestibility, and $\mathrm{CH}_{4}$ production.

\section{MATERIALS AND METHODS}

Animal care and handling was approved by the University of Nevada, Reno Institutional Animal Care and Use Committee (protocol no. 00588).

\section{Experiment 1}

Diets and Experimental Design. Three diets were formulated to meet or exceed the dairy NRC recommendations (NRC, 2001) using as a reference a Holstein cow that produced $44 \mathrm{~kg}$ of milk, was 120 DIM, and had a BW of $660 \mathrm{~kg}$. Diets were fed as TMR and contained (DM basis) $15 \%$ wheat straw, $25 \%$ orchard hay, and $60 \%$ concentrate. Dietary treatments were (1) SBM with $42.6 \%$ of RUP as a percentage of CP (NRC, 2001), (2) LCM (38\% of RUP; Broderick et al., 2016), and (3) HCM (50\% RUP; Broderick et al., 2016). Chemical composition of the diets is shown in Table 1. Chemical composition of the protein supplements is shown in Table 2. All ingredients were ground to pass through a 2-mm screen in a Wiley mill (model no. 2, Arthur H. Thomas Co., Philadelphia, PA). The diets were formulated to contain $18 \% \mathrm{CP}$; however, after feed analysis we found greater contents of CP for all ingredients used in the diets. Therefore, the final diet fed to the fermentors contained $21 \%$ of CP. Each fermentor was fed 72 $\mathrm{g} / \mathrm{d}$ of DM equally divided into 4 meals at 0600,1200 ,
Table 1. Ingredient and chemical composition of diets (\% of DM unless otherwise stated)

\begin{tabular}{|c|c|c|c|}
\hline \multirow[b]{2}{*}{ Item } & \multicolumn{3}{|c|}{$\operatorname{Diet}^{1}$} \\
\hline & SBM & $\mathrm{LCM}$ & $\mathrm{HCM}$ \\
\hline Orchard hay & 25.0 & 25.0 & 25.0 \\
\hline Wheat straw & 15.0 & 15.0 & 15.0 \\
\hline Ground corn & 32.5 & 24.3 & 23.0 \\
\hline SBM & 25.0 & - & - \\
\hline $\mathrm{LCM}$ & - & 33.2 & - \\
\hline $\mathrm{HCM}$ & - & - & 34.5 \\
\hline Vitamin and mineral premix & 2.5 & 2.5 & 2.5 \\
\hline \multicolumn{4}{|l|}{ Chemical composition } \\
\hline OM & 91.5 & 90.9 & 90.6 \\
\hline $\mathrm{CP}$ & 21.5 & 20.7 & 20.6 \\
\hline $\mathrm{RDP}^{2}$ & 14.5 & 13.2 & 12.9 \\
\hline RUP $^{2}$ & 7.0 & 7.5 & 7.7 \\
\hline $\mathrm{RDP}^{3}$ & 13.3 & 13.1 & 12.6 \\
\hline RUP $^{4}$ & 8.2 & 7.7 & 8.1 \\
\hline NDF & 31.1 & 37.8 & 37.5 \\
\hline $\mathrm{ADF}$ & 18.2 & 24.5 & 25.2 \\
\hline $\mathrm{NFC}^{5}$ & 41.3 & 36.0 & 36.3 \\
\hline Ether extract & 2.22 & 2.15 & 1.82 \\
\hline NDIN, $\%$ of total N & 7.7 & 15.9 & 14.8 \\
\hline $\mathrm{NE}_{\mathrm{L}},{ }^{6} \mathrm{Mcal} / \mathrm{kg}$ of $\mathrm{DM}$ & 1.58 & 1.50 & 1.50 \\
\hline
\end{tabular}

${ }^{1} \mathrm{SBM}=$ solvent-extracted soybean meal; LCM $=$ low-RUP solventextracted canola meal ( $38 \%$ RUP as a percentage of $\mathrm{CP}) ; \mathrm{HCM}=$ high-RUP solvent-extracted canola meal ( $50 \%$ RUP).

${ }^{2}$ Estimated using the NRC (2001) model.

${ }^{3}$ Calculated from in vitro dual-flow continuous culture measurements as RDP $(\%$ of $\mathrm{DM})=$ total $\mathrm{CP}$ intake $(\mathrm{g} / \mathrm{d})$ - effluent RUP flow $(\mathrm{g} / \mathrm{d})] \times 100 / \mathrm{DMI}(\mathrm{g} / \mathrm{d})$. Adapted from Reynal and Broderick (2005) . ${ }^{4}$ Calculated from in vitro dual-flow continuous culture measurements as RUP $(\%$ of DM $)=$ total effluent CP flow $(\mathrm{g} / \mathrm{d})-$ effluent bacterial CP flow (g/d)] × 100/DMI (g/d). Adapted from Reynal and Broderick (2005).

${ }^{5} \mathrm{NFC}=100-(\% \mathrm{NDF}+\% \mathrm{CP}+\%$ fat $+\%$ ash $)+\% \mathrm{NIDN} \times 6.25$ according to the NRC (2001) model.

${ }^{6}$ Estimated using the NRC (2001) model.

1800, and $2400 \mathrm{~h}$. Diets were randomly assigned within squares to 6 dual-flow continuous culture fermentors in a replicated $3 \times 3$ Latin square arrangement with three 10-d experimental periods consisting of $7 \mathrm{~d}$ for diet adaptation and $3 \mathrm{~d}$ for sample collection.

Dual-Flow Continuous Culture System. For this study, 6-unit dual-flow continuous culture fermentors (Omni-Culture Plus; Virtis Co. Inc., Gardiner, NY) originally developed by Hoover et al. (1976) and recently modified by Benedeti et al. (2015) and Silva et al. (2016) were used. Ruminal fluid was collected approximately $2 \mathrm{~h}$ after feeding from 2 rumen-cannulated steers (average $\mathrm{BW}=550 \mathrm{~kg}$ ). The donor steers were fed (DM basis) a 60:40 forage:concentrate diet containing $60 \%$ grass hay, $27.5 \%$ ground corn, $10 \%$ SBM, and $2.5 \%$ vitamin premix. Ruminal digesta was manually collected and strained through 4 layers of cheesecloth, and approximately $10 \mathrm{~L}$ of ruminal fluid was poured into a prewarmed insulated vessel. The rumen fluid was pooled and homogenized, infused with $\mathrm{N}_{2}$ to maintain 
Table 2. Chemical composition of the protein supplements (\% of DM unless otherwise stated)

\begin{tabular}{|c|c|c|c|}
\hline \multirow[b]{2}{*}{ Chemical composition } & \multicolumn{3}{|c|}{ Protein supplement ${ }^{1}$} \\
\hline & SBM & $38 \%$ RUP CM & $50 \%$ RUP CM \\
\hline $\mathrm{OM}$ & 92.7 & 92.5 & 91.8 \\
\hline $\mathrm{CP}$ & 54.9 & 43.6 & 42.1 \\
\hline $\mathrm{RDP}$ & $31.5^{2}$ & $26.9^{3}$ & $21.2^{3}$ \\
\hline RUP & $23.4^{2}$ & $16.7^{3}$ & $20.9^{3}$ \\
\hline $\mathrm{NDF}$ & 10.3 & 30.4 & 28.7 \\
\hline $\mathrm{ADF}$ & 6.2 & 23.0 & 24.2 \\
\hline $\mathrm{NFC}^{4}$ & 27.1 & 18.1 & 18.0 \\
\hline Ether extract & 1.1 & 1.66 & 0.81 \\
\hline NDIN, \% of total N & 0.5 & 25.3 & 21.3 \\
\hline $\mathrm{ME},{ }^{5} \mathrm{Mcal} / \mathrm{kg}$ of $\mathrm{DM}$ & 3.41 & 2.75 & 2.75 \\
\hline \multicolumn{4}{|c|}{${ }^{1} \mathrm{SBM}=$ standard soybean meal; $38 \%$ RUP CM $=$ canola meal with $38 \%$ RUP; $50 \%$ RUP CM = canola meal } \\
\hline \multicolumn{4}{|c|}{${ }^{2}$ Estimated using the NRC (2001) model for a cow with DMI $=4 \%$ of $\mathrm{BW}$. } \\
\hline \multicolumn{4}{|c|}{${ }^{3}$ Estimated according to Broderick et al. (2016). } \\
\hline \multicolumn{4}{|c|}{${ }^{4} \mathrm{NFC}=100-(\% \mathrm{NDF}+\% \mathrm{CP}+\%$ fat $+\%$ ash $)+\mathrm{NDIN} \times 6.25$ according to NRC $(2001)}$. \\
\hline
\end{tabular}

the anaerobic environment, and kept at $39^{\circ} \mathrm{C}$ in a 5,000$\mathrm{mL}$ Erlenmeyer flask in a preheated water bath. The rumen fluid was poured into each of the prewarmed fermentors until it cleared the effluent spout.

Fermenter contents were continuously stirred by a central propeller apparatus driven by magnets at the rate of $150 \mathrm{rpm}$. Artificial saliva (Weller and Pilgrim, 1974) was continuously infused at $2.2 \mathrm{~mL} / \mathrm{min}$. Liquid and solid dilution rates were adjusted daily to 11 and $5.5 \% / \mathrm{h}$, respectively, by adjusting buffer input and liquid and solid removal. Individual $\mathrm{pH}$ controllers (ColeParmer model 5997-20; Vernon Hills, IL) were used to monitor the $\mathrm{pH}$ of each fermentor.

On d 5, effluent digesta (liquid and solid) were homogenized and samples collected to determine the background ${ }^{15} \mathrm{~N}$ abundance. Then, $0.077 \mathrm{~g}$ of $\left({ }^{15} \mathrm{NH}_{4}\right)_{2} \mathrm{SO}_{4}$ with $10.2 \%$ atom excess of ${ }^{15} \mathrm{~N}$ (Sigma-Aldrich Co., St. Louis, MO) was infused into each fermentor to instantaneously label the $\mathrm{NH}_{3}$ - N pool. Saliva was reformulated to contain $0.077 \mathrm{~g} / \mathrm{L}$ of the enriched $\left({ }^{15} \mathrm{NH}_{4}\right)_{2} \mathrm{SO}_{4}$ to replace an isonitrogenous amount of urea to obtain a steady-state ${ }^{15} \mathrm{~N}$ enrichment of the $\mathrm{NH}_{3}$ pool in the fermentors (Calsamiglia et al., 1996).

Liquid and solid effluents were collected in 4.3-L plastic containers. During the first $7 \mathrm{~d}$ (adaptation period), the effluent containers were weighed once daily at $0600 \mathrm{~h}$ and the contents were discarded. Twenty-four hours before the first collection and during the 3-d sampling period, liquid and solid effluent containers were immersed in a chilled water bath at $2^{\circ} \mathrm{C}$, and $20 \mathrm{~mL}$ of $50 \% \mathrm{H}_{2} \mathrm{SO}_{4}$ was added to each container to prevent further microbial and enzymatic activities.

On d 8, 9, and 10, liquid and solid digesta effluents from each fermentor were taken and homogenized for
1 min (T25 basics, IKA Works Inc., Wilmington, NC), and $500 \mathrm{~mL}$ was removed via a vacuum system and stored at $-20^{\circ} \mathrm{C}$ for later analysis of $\mathrm{DM}, \mathrm{OM}, \mathrm{CP}$, $\mathrm{NDF}$, and ADF. Additionally, two 10-mL subsamples were filtered through 8 layers of cheesecloth, preserved with $0.2 \mathrm{~mL}$ of $0.2 \mathrm{~N}$ sulfuric acid, and centrifuged at $1,000 \times g$ for $15 \mathrm{~min}$ at $4^{\circ} \mathrm{C}$. The supernatant was decanted and stored at $-20^{\circ} \mathrm{C}$ for subsequent ruminal $\mathrm{NH}_{3}-\mathrm{N}$ and VFA analysis. Fermenter $\mathrm{pH}$ was measured with an Accumet portable AP61 pH meter (Fisher Scientific, Atlanta, GA) at 0600, 0800, 0900, 1000, and $1100 \mathrm{~h}$.

On d 10, the entire fermentor contents were strained through 2 layers of cheesecloth and centrifuged at $1,000 \times g$ for $10 \mathrm{~min}$ at $5^{\circ} \mathrm{C}$. Then, the supernatant was centrifuged (Sorvall RC-5B refrigerated superspeed centrifuge; DuPont, Wilmington, DE) at 20,000 $\times g$ for $20 \mathrm{~min}$ at $5^{\circ} \mathrm{C}$. The supernatant was discarded, and bacterial pellets were freeze dried and stored for further analysis of ${ }^{15} \mathrm{~N}, \mathrm{~N}$, and OM (Bach et al., 2008).

Chemical Analyses. Feed and effluent samples were analyzed for DM (method 934.01), ether extract (method 920.85), and ash (method 938.08) according to AOAC (1990). The CP content of feed samples was determined using a Leco combustion nitrogen analyzer (Leco CN628 Carbon/Nitrogen Analyzer, Leco Instruments Inc., St. Joseph, MI; method 990.13, AOAC International, 2005). The OM content was calculated as the difference between DM and ash contents. For $\mathrm{NDF}$, samples were analyzed, treated with thermostable $\alpha$-amylase and sodium sulfite according to Mertens (2002), and adapted for the Ankom200 Fiber Analyzer (Ankom Technology, Macedon, NY). For ADF, samples were sequentially analyzed according to Van Soest and 
McQueen (1973) and adapted for the Ankom200 Fiber Analyzer. Neutral detergent-insoluble CP (NDICP) was isolated by gravimetric determination using thermostable $\alpha$-amylase and sodium sulfite followed by $\mathrm{CP}$ analysis (method 990.13; AOAC International, 2005). The NFC concentration of the feed ingredients was calculated using the equation $\mathrm{NFC}=100-(\% \mathrm{NDF}+\%$ $\mathrm{CP}+\%$ ether extract $+\%$ ash) $+\mathrm{NDICP}$ (according to NRC, 2001).

Concentration of VFA of the effluent samples was determined with a gas chromatograph (model 3800; Varian Inc., Walnut Creek, CA) equipped with a glass column $(180 \mathrm{~cm} \times 4 \mathrm{~mm}$ i.d. $)$ packed with GP $10 \%$ SP-1200/1\% $\mathrm{H}_{3} \mathrm{PO}_{4}$ on 80/100 Chromosorb WAW (Supelco, Bellefonte, PA); $\mathrm{N}_{2}$ was used as a carrier gas at a flow rate of $85 \mathrm{~mL} / \mathrm{min}$. The oven, injection port, and detector port temperatures were 125, 175, and $180^{\circ} \mathrm{C}$, respectively. Ruminal $\mathrm{NH}_{3}-\mathrm{N}$ concentration was determined according to Chaney and Marbach (1962). Bacterial and effluent digesta samples were analyzed for total $\mathrm{N}$ as previously described. Bacterial, effluent digesta, and background samples were analyzed for enrichment with ${ }^{15} \mathrm{~N}$ using a Eurovector model 3000 elemental analyzer (Euro EA 3000, Eurovector S.P.A., Milano, Italy) interfaced to a Micromass Isoprime stable isotope ratio mass spectrometer (IsoPrime, Micromass UK Ltd., Manchester, UK; Werner et al., 1999).

Calculations. Bacterial N flow and bacterial efficiency were calculated according to Calsamiglia et al. (1996) as follows:

$$
\begin{gathered}
\text { sample }{ }^{15} \mathrm{~N} \text { enrichment (atom percentage excess) }= \\
\text { sample }{ }^{15} \mathrm{~N} \text { atom } \% \text { - background }{ }^{15} \mathrm{~N} \text { atom } \% \text {, } \\
\text { bacterial } \mathrm{N} \text { flow }(\mathrm{g} / \mathrm{d})=(\mathrm{NAN} \text { flow } \times \text { atom } \\
\text { percentage excess of } \left.{ }^{15} \mathrm{~N} \text { of effluent }\right) / \\
\text { (atom percentage excess of }{ }^{15} \mathrm{~N} \text { of bacteria), and } \\
\text { bacterial efficiency }=\text { bacterial } \mathrm{N} \text { flow }(\mathrm{g}) / \\
\text { OM truly digested }(\mathrm{kg}) .
\end{gathered}
$$

True ruminal (DM, OM, CP, NDF, ADF) digestibilities were calculated as follows (using DM as an example):

$$
\begin{gathered}
\text { true DM digestibility }(\%)=[\mathrm{g} \text { of dietary DM } \\
-(\mathrm{g} \text { of effluent } \mathrm{DM}-\mathrm{g} \text { of saliva } \mathrm{DM} \\
-\mathrm{g} \text { of bacterial } \mathrm{DM})] /(\mathrm{g} \text { of dietary } \mathrm{DM}) \times 100 \text {. }
\end{gathered}
$$

Nitrogen flows were calculated as follows:

$$
\begin{aligned}
& \mathrm{NH}_{3}-\mathrm{N} \text { flow }(\mathrm{g} / \mathrm{d})=\mathrm{mg} / \mathrm{dL} \text { of effluent } \mathrm{NH}_{3}-\mathrm{N} \\
& \quad \times(\mathrm{g} \text { of total effluent flow } / 100), \\
& \quad \mathrm{NAN} \text { flow }(\mathrm{g} / \mathrm{d})=\mathrm{g} \text { of effluent } \mathrm{N} \\
& \quad-\mathrm{g} \text { of effluent } \mathrm{NH}_{3}-\mathrm{N}, \\
& \text { dietary } \mathrm{N} \text { flow }(\mathrm{g} / \mathrm{d})=\mathrm{g} \text { of effluent } \mathrm{NAN} \\
& -\mathrm{g} \text { of effluent bacterial } \mathrm{N}, \\
& \text { RUP-N flow }(\mathrm{g} / \mathrm{d})=\text { total } \mathrm{N} \text { flow } \\
& - \text { effluent bacterial } \mathrm{N} \text { flow, and }
\end{aligned}
$$

RDP-N supply $(\mathrm{g} / \mathrm{d})=$ total $\mathrm{N}$ intake - RUP-N flow.

\section{Experiment 2}

Experiment 2 aimed to evaluate ruminal gas production kinetics, in vitro $\mathrm{OM}$ digestibility, and $\mathrm{CH}_{4}$ and ATP production from the 3 diets used in experiment 1. A gas production apparatus (Ankom RF gas production system, Ankom Technology) equipped with pressure sensors that were wirelessly connected to a computer was used. The experimental design was 3 incubation runs $\times 3$ diets $\times 6$ bottles per treatment plus 18 blank bottles ( 6 per run), totaling 72 units. Dietary treatments were similar to those used in experiment 1 (Table 1) with the exception that the mineral premix was not used. The mineral premix used in experiment 1 was not used in experiments 2 and 3 because in experiments 2 and 3 a buffer-mineral solution was used as recommended by Tagliapietra et al. (2011) and Menke and Steingass (1988), providing all minerals needed for microbial growth.

Feed ingredients were ground to pass through a 1-mm screen in a Wiley mill (model no. 2; Arthur H. Thomas Co.). Each bottle $(620 \mathrm{~mL})$ was filled with $0.5 \mathrm{~g}$ of each diet. Samples were hydrated with deionized water to avoid particle dispersion. The buffer mineral solution was prepared according to Menke and Steingass (1988) except for the addition of sodium sulfite and L-cysteine. The buffer mineral solution was kept in a water bath at $39^{\circ} \mathrm{C}$ and purged continuously with $\mathrm{N}_{2}$ infusion for $30 \mathrm{~min}$. The resazurin solution was used as a color indicator for monitoring buffer $\mathrm{pH}$ and $\mathrm{N}_{2}$ saturation (oxidation-reduction potential). Rumen fluid was collected from the same animals used in experiment 1 , which were on the same diet described previously. Two hours after feeding, $2 \mathrm{~L}$ of rumen fluid was collected, immediately filtered through 4 layers of cheesecloth, and held in prewarmed thermal containers $\left(39^{\circ} \mathrm{C}\right)$. The rumen fluid was mixed with the buffer 
solution $(1: 2 \mathrm{vol} / \mathrm{vol})$ in a water bath at $39^{\circ} \mathrm{C}$ under anaerobic conditions by flushing with $\mathrm{N}_{2}$ (Menke and Steingass, 1988). Bottles were inoculated with $75 \mathrm{~mL}$ of rumen fluid-buffer mixture solution while the bottle headspace was continuously flushed with $\mathrm{N}_{2}$. Bottles without feed samples but with the rumen fluid-buffer mixture solution were used as blanks to correct for rumen inoculum fermentation. After inoculation, bottles were closed and placed in an air-ventilated shaker incubator (Innova 4400 incubator shaker; New Brunswick Scientific, Edison, NJ) under controlled temperature and agitation $\left(39^{\circ} \mathrm{C}\right.$ and $\left.80 \mathrm{rpm}\right)$. The data acquisition software (Gas Pressure Monitor, Ankom Technology) was set to record cumulative pressure every $15 \mathrm{~min}$ for $48 \mathrm{~h}$. Valves were set to automatically release the gas when the pressure reached $3.4 \mathrm{kPa}$ (Tagliapietra et al., 2011). At the beginning $(0 \mathrm{~h})$ and end $(48 \mathrm{~h})$ of the incubation, the solution $\mathrm{pH}$ was measured with an Accumet portable AP61 pH meter (Fisher Scientific).

At the end of the incubation, $10-\mathrm{mL}$ subsamples were filtered through 2 layers of cheesecloth from half of the bottles ( 9 observations per treatment), and 0.2 $\mathrm{mL}$ of a $50 \% \mathrm{H}_{2} \mathrm{SO}_{4}$ solution was added for later VFA determination and $\mathrm{CH}_{4}$ production calculation. All the remaining bottles (9 observations per treatment) were stored and freeze dried for later determinations of DM and NDF.

\section{Experiment 3}

Experimental Procedures and Substrates. Experiment 3 evaluated ruminal gas production kinetics, in vitro $\mathrm{OM}$ digestibility, and $\mathrm{CH}_{4}$ and ATP production from the 3 protein supplements as a sole ingredient. This experiment used the same gas production apparatus system, experimental design, and 3 protein supplements used in experiments 1 and 2 . The chemical composition of the ingredients is shown in Table 2. The 3 protein supplements were also ground to pass through a 1-mm screen in a Wiley mill (model no. 2; Arthur H. Thomas Co.). As described earlier for experiment 2, at the end of the incubation, half of the bottles were used for VFA sampling and the remaining bottles were stored for later DM and NDF determination.

Chemical Analysis and Calculations (Experiments 2 and 3). The 3 protein supplements and the ingredients used in the experimental diets were analyzed for DM, OM, CP, NDF, ADF, NDIN, and NDF as described in experiment 1 . The VFA concentrations were determined using gas chromatography as described in experiment 1. Postfermentation freeze-dried samples were analyzed for DM and subsequently for NDF.

Calculations (Experiments 2 and 3). The ATP and $\mathrm{CH}_{4}$ production was estimated according to Owens and Goetsch (1988) through VFA stoichiometry using the following equations:

$$
\begin{gathered}
\text { ATP }=(1 / 4 \text { acetate })+(23 / 4 \text { propionate }) \\
+(31 / 2 \text { butyrate }) \\
\mathrm{CH}_{4}=(1 / 2 \text { acetate })+(1 / 2 \text { butyrate }) \\
\quad-(1 / 4 \text { propionate }) .
\end{gathered}
$$

The in vitro true OM digestibility (\%) was calculated as $(\mathrm{iOM}-\mathrm{rNDF}) / \mathrm{iOM}$, where $\mathrm{iOM}$ is the incubated $\mathrm{OM}$ and rNDF is the residual NDF after $48 \mathrm{~h}$ of digestion minus the NDF content in the blank bottles.

For cumulative pressure $(\mathrm{kPa})$, the gas pressure was converted to units of volume according to Tagliapietra et al. (2011) that used the ideal gas law in which gas pressure $(\mathrm{mL})=(\mathrm{Pc} / \mathrm{Po}) \times \mathrm{Vo}$, where $\mathrm{Pc}$ is the cumulated pressure change $(\mathrm{kPa})$ in the bottle headspace, Vo is the bottle headspace volume $(545 \mathrm{~mL})$, and Po is the atmospheric pressure read by the equipment at the beginning of the measurement. The in vitro digestibility and the final gas production volumes were corrected by subtracting the blank bottle values.

\section{Statistical Analysis}

Experiment 1. Data were analyzed using the MIXED procedure of SAS 9.4 (SAS, 2002) as a replicated $3 \times 3$ Latin square design according to the following model:

$$
\mathrm{Y}_{i j k l}=\mu+S_{i}+P_{j}+F(S)_{k i}+D_{l}+E_{i j k l},
$$

where $Y_{i j k l}$ is the dependent variable, $\mu$ is the overall mean, $S_{i}$ is the fixed effect of Latin square $(i=1$ or 2$)$, $P_{j}$ is the fixed effect of period $(j=1-3), F(S)_{k i}$ is the random effect of fermentor $(F)$ within square $(k=1-6)$, $D_{l}$ is the fixed effect of diet ( $l=\mathrm{SBM}, \mathrm{LCM}$, or HCM), and $E_{i j k l}$ is the residual error. Orthogonal contrasts were constructed to evaluate the effect of the different protein supplements as follows: (1) SBM versus LCM + HCM and (2) LCM versus HCM. Least squares means and standard error of the mean are reported for all data, with significance declared at $P \leq 0.05$ and trends at $0.05>P \leq 0.10$. Ruminal $\mathrm{pH}$ data were analyzed as repeated measures according to the following model:

$$
\begin{aligned}
Y_{i j k l m}=\mu+ & S_{i}+P_{j}+F(S)_{k i}+D_{l}+T_{m} \\
& +D T_{l m}+E_{i j k l m},
\end{aligned}
$$

where $\mathrm{Y}_{i j k l m}$ is the dependent variable, $\mu$ is the overall mean, $S_{i}$ is the fixed effect of Latin square $(i=1$ or 
2), $P_{j}$ is the fixed effect of period $(j=1-3), F(S)_{k i}$ is the random effect of fermentor $(F)$ within square $(k=$ $1-6), D_{l}$ is the fixed effect of diet $(l=\mathrm{SBM}, \mathrm{LCM}$, or $\mathrm{HCM}), T_{m}$ is the fixed effect of time $(m=1-5), D T_{l m}$ is the interaction between diet and time, and $E_{i j k l m}$ is the residual error. The effect of fermentor within diet was used as the error term to test the effect of diet. The covariance structure used was the one with the smaller value for the Akaike information criterion.

Experiments 2 and 3. Data were analyzed using the MIXED procedure of SAS 9.4 (SAS Institute, 2002) with a statistical model including fixed effect of treatment and random effect of run. Orthogonal contrasts were as described for experiment 1. An exponential model with lag phase was fitted to the cumulative gas production using the NLIN procedure of SAS 9.4 (SAS Institute, 2002) to analyze ruminal gas production kinetics over $48 \mathrm{~h}$ in experiments 2 and 3. Least squares means and standard error of the mean are reported for all data. Significance was declared at $P \leq 0.05$, and trends were declared at $0.05<P \leq 0.10$.

\section{RESULTS AND DISCUSSION}

\section{Experiment 1}

Ruminal $p H$ and $N$ Metabolism. No differences in rumen $\mathrm{pH}$ were found across diets. The average for all dietary treatments was 6.4 ; a minor variation was found between feed intervals (minimum $=6.4$; maximum $=6.6$ ). Bach et al. (2005) noted that ruminal $\mathrm{pH}$ lower than 5.5 could decrease protein degradation; therefore, in the present study, $\mathrm{pH}$ likely did not affect protein degradation.

Diet had no effect $(P>0.05)$ on ammonia N concentration, total N, NAN, bacterial N, dietary N, RUP-N flows, RDP-N supply, efficiency of $\mathrm{N}$ utilization, and efficiency of bacterial N synthesis (Table 3). Although there was a trend $(P=0.09)$ for lower $\mathrm{NH}_{3}-\mathrm{N}$ flow when SBM was fed, the values observed were too similar to reflect in a meaningful biological response. It is important to highlight that in the present study all treatments were adjusted to receive the same amount of feed $(72 \mathrm{~g} / \mathrm{d}$ on a DM basis) and to have the same ruminal passage rate. Therefore, we were able to minimize the possible effects of DMI and passage rate on $\mathrm{N}$ metabolism. Two meta-analysis studies (Huhtanen et al., 2011; Martineau et al., 2013) reported an increase in DMI for diets supplemented with CM compared with SBM. Huhtanen et al. (2011) suggested that CM diets provide a better AA supply and support greater milk yield, which increases energy demand and consequently increases DMI. Therefore, because in our study we did not find any significant difference in $\mathrm{N}$ metabolism among the CM and SBM diets, it is possible that the positive effects of $\mathrm{CM}$ on $\mathrm{N}$ metabolism and milk production are correlated with the increase in DMI and a potentially better AA supply for CM diets compared with SBM diets.

Although the high dietary CP might have played a role in ruminal $\mathrm{N}$ fermentation, especially with regards to $\mathrm{RDP}$ and $\mathrm{NH}_{3}-\mathrm{N}$ levels, previous studies with 16.5 and $15.7 \% \mathrm{CP}$, respectively, reported similar results with regards to ruminal $\mathrm{N}$ metabolism when comparing

Table 3. Effects of different protein supplements on $\mathrm{pH}$ and $\mathrm{N}$ metabolism in dual-flow continuous culture (experiment 1)

\begin{tabular}{|c|c|c|c|c|c|c|}
\hline Item & \multicolumn{3}{|c|}{ Treatment $^{1}$} & SEM & \multicolumn{2}{|c|}{$P$-value ${ }^{2}$} \\
\hline $\mathrm{NH}_{3}-\mathrm{N}, \mathrm{mg} / \mathrm{dL}$ & 15.7 & 17.6 & 16.3 & 0.67 & 0.12 & 0.17 \\
\hline \multicolumn{7}{|l|}{$\mathrm{N}$ flows, g/d } \\
\hline Total N & 2.51 & 2.41 & 2.44 & 0.05 & 0.24 & 0.67 \\
\hline Dietary N & 0.44 & 0.31 & 0.40 & 0.05 & 0.23 & 0.28 \\
\hline RUP-N & 0.94 & 0.88 & 0.93 & 0.05 & 0.57 & 0.54 \\
\hline RDP-N supply & 2.07 & 2.04 & 1.98 & 0.07 & 0.44 & 0.47 \\
\hline $\mathrm{ENU}^{3} \%$ & 76.0 & 74.8 & 76.3 & 2.27 & 0.86 & 0.66 \\
\hline Bacterial efficiency ${ }^{4}$ & 46.5 & 45.7 & 46.7 & 2.45 & 0.90 & 0.77 \\
\hline
\end{tabular}

${ }^{1} \mathrm{SBM}=$ solvent-extracted soybean meal; LCM $=$ low-RUP solvent-extracted canola meal (38\% RUP as a percentage of CP); HCM $=$ high-RUP solvent-extracted canola meal (50\% RUP).

${ }^{2}$ Orthogonal contrasts for effects of different protein supplements (SBM vs. LCM + HCM and LCM vs. HCM).

${ }^{3}$ Efficiency of $\mathrm{N}$ use $=\mathrm{g}$ of bacterial N/g of available N (Bach and Stern, 1999).

${ }^{4}$ Bacterial efficiency $=\mathrm{g}$ of bacterial $\mathrm{N} / \mathrm{kg}$ of OM truly digested. 
SBM and CM (Brito and Broderick, 2007; Paula et al., 2016a). This suggests that dietary CP levels play a minor role when comparing these 2 protein supplements. Lower CP levels would have made it challenging to evaluate RUP flow because low CP levels would leave little room for RUP differences among treatments. For example, a $16 \%$ dietary $\mathrm{CP}$ would yield a difference of only $19.2 \mathrm{~g}$ of RUP $/ \mathrm{kg}$ of DMI between the $2 \mathrm{CM}$ diets tested (38 and 50\% RUP as a percentage of CP) as opposed to $25.2 \mathrm{~g}$ of RUP $/ \mathrm{kg}$ of DMI in a $21 \%$ dietary CP level. Nevertheless, high CP levels may have precluded better evaluation of ruminal $\mathrm{N}$ fermentation.

We observed that the values for NAN, bacterial N, dietary $\mathrm{N}$ flows, and RDP-N supply were similar among the diets, indicating that ruminal CP degradability is similar between the CM and SBM diets. However, most feed tables (AFRC, 1993; NRC, 2001; INRA, 2007) report greater MP for SBM compared with CM because of its lower CP degradability and greater RUP content (Huhtanen et al., 2011). It is possible that feed tables have inaccurate CM RUP and RDP values, which could be attributable to methodological assessments of RDP and RUP. For example, early studies reporting CM RDP and RUP fraction used in situ methodology, which assumes that soluble proteins, peptides, and AA are completely degraded in the rumen, which may not always be the case (Reynal et al., 2007). Furthermore, Hedqvist and Udén (2006) have shown that the ruminal degradation rate of the soluble protein fraction of CM is lower than previously thought. In addition, Bach et al. (2008) found that $63 \%$ of the soluble CP fraction in CM may escape from rumen degradation. Also, in situ methodologies may impose physical restrictions to feed within the bags and contain microbial contamination in undigested residues (Broderick et al., 1991). Another possible reason for the discrepancy in CM RUP and RDP values in feed tables may be differences in seed processing or crushing methods. For example, NRC (2001) lists only mechanically extracted CM (expeller $\mathrm{CM}$ ); however, solvent extraction of the CM is the primary method that is currently being used.

Maxin et al. (2013), evaluating in situ CP ruminal degradation of SBM and CM, observed lower CP degradability and greater RUP content for CM compared with SBM. Broderick et al. (2015) observed a significant decrease in ruminal $\mathrm{NH}_{3}-\mathrm{N}$ concentration for $\mathrm{CM}$ compared with SBM in lactating dairy cows. Furthermore, Brito et al. (2007) estimated numerical in vivo RUP flows of 29 and $34 \%$ (of CP) for SBM and CM diets, respectively. Therefore, our results are in agreement with previous results in the literature indicating that MP, RDP, and RUP content of CM should be revised in the feed tables to more accurately reflect the MP of $\mathrm{CM}$ in feed protein evaluation systems.
We did not observe differences in RUP flow, which was surprising given the magnitude of RUP differences between the CM sources that were used. For example, considering an average of $21 \%$ dietary CP, for the LCM diet $79.8 \mathrm{~g}$ of RUP was consumed for each $1 \mathrm{~kg}$ of DMI, whereas for the HCM diet $105 \mathrm{~g}$ of RUP was consumed for each $1 \mathrm{~kg}$ of DMI. The difference may not have been enough to affect ruminal $\mathrm{N}$ metabolism. Another possible explanation would be that the RUP values measured in the $\mathrm{CM}$ as a single ingredient (Broderick et al., 2016) may be slightly different when TMR were fed, meaning that possible interactions among ingredients may affect protein degradation.

$\boldsymbol{V F A}$. Dietary treatments did not affect total VFA concentration; molar proportions of acetate, propionate, and isobutyrate; and acetate:propionate ratio (Table 4). These results are in agreement with other studies comparing SBM with CM, in which significant differences for total VFA and VFA molar proportions were not found (Sanchez and Claypool, 1983; Brito and Broderick, 2007). However, there were trends for increasing total VFA concentration $(P=0.08)$ and molar proportion of butyrate $(P=0.06)$ for the SBM diet compared with both CM diets. This might be attributable to greater NFC content in the SBM diet compared with the CM diets (41.3, 36.0, and $36.3 \%$, respectively), which could contribute to more microbial fermentation compared with the CM diets. Testing SBM and CM as protein supplements, Brito and Broderick (2007) had diets differing in NFC content at approximately 4 percentage units (50.2 and $46.4 \%$ for SBM and CM, respectively) and did not find differences in total VFA and molar proportions of acetate and propionate. Moreover, also comparing SBM and CM, Broderick et al. (2015) had diets differing in NFC content at approximately 3 percentage units (47.8 and $44.5 \%$ for SBM and CM, respectively) and did not find differences in total VFA and molar proportions of acetate and propionate. Therefore, despite the NFC differences in the current study, it is unlikely that this difference played a major role in ruminal fermentation.

The molar proportion of valerate was greater $(P=$ 0.01 ) when $\mathrm{CM}$ was fed, whereas molar proportions of isovalerate $(P=0.02)$ and total BCVFA were lower $(P$ $=0.04$ ) for CM diets. Ruminal BCVFA are products of branched-chain AA (valine, isoleucine, and leucine) oxidative deamination and decarboxylation (Allison and Bryant, 1963). Therefore, these BCVFA are associated with degradation of the branched-chain AA leucine, isoleucine, and valine, suggesting less degradation of these branched-chain AA for CM diets. In agreement with our findings, Broderick et al. (2015) reported a decrease in ruminal isovalerate and total BCVFA when CM replaced SBM in diets fed to lactating dairy cows. 
Table 4. Effects of different protein supplements on VFA concentration in dual-flow continuous culture (experiment 1)

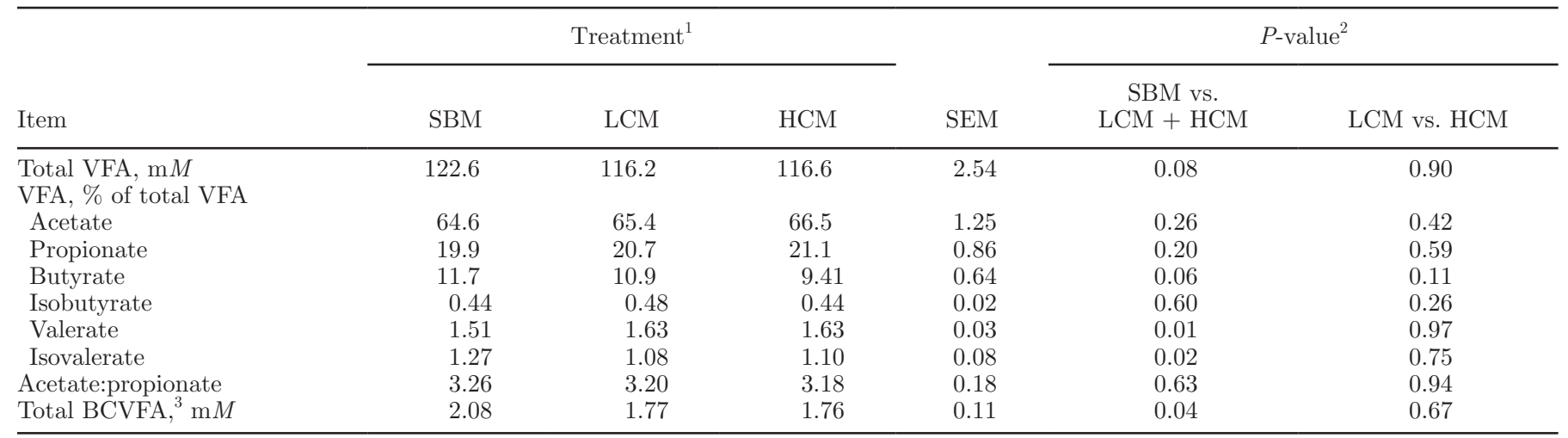

${ }^{1} \mathrm{SBM}=$ solvent-extracted soybean meal; LCM $=$ low-RUP solvent-extracted canola meal (38\% RUP as a percentage of CP); HCM $=$ high-RUP solvent-extracted canola meal (50\% RUP).

${ }^{2}$ Orthogonal contrasts for effects of different protein supplements (SBM vs. LCM + HCM and LCM vs. HCM).

${ }^{3} \mathrm{BCVFA}=$ branched-chain VFA.

Ruminal True Digestibility. Ruminal true digestibility was not affected by dietary treatments (Table 5). The average values for true DM, OM, NDF, and ADF ruminal digestibility were $43.3,52.0,74.8$, and $66.4 \%$, respectively. Because the main focus was on protein supplements, diets were relatively similar. Therefore, it was not expected that there would be major differences in DM, OM, and fiber digestibilities. Brito et al. (2007) evaluated the effect of different protein supplements on omasal nutrient flow in lactating dairy cows and did not observe significant differences for ruminal degradability of DM, OM, NDF, and ADF between the SBM and CM treatments, which agrees with our findings. In a review and meta-analysis evaluating $\mathrm{CM}$ as a protein supplement for dairy cows, Huhtanen et al. (2011) did observe reduced total-tract true $\mathrm{CP}$ digestibility for heat-treated CM diets compared with untreated CM diets. In the present study, there were no significant differences in ruminal $\mathrm{CP}$ digestibility between LCM and HCM diets. It is important to highlight that herein we measured ruminal CP digestibility only as opposed to total-tract CP digestibility. Similar to our results,
Ahvenjärvi et al. (1999) did not observe differences in ruminal CP digestibility between rapeseed meal and heat-moisture-treated rapeseed cake for lactating dairy cows. In addition, in another study we did not observe a difference in ruminal $\mathrm{CP}$ digestibility between regular $\mathrm{CM}$ and heat-treated CM; however, we did observe a tendency for a decrease in apparent total-tract CP digestibility for the heat-treated CM diet compared with the regular CM diet (Paula et al., 2016b). Therefore, it is likely that the lack of effects on ruminal CP digestibility between $\mathrm{CM}$ diets may be attributable to the small difference in RUP content between the diets.

\section{Experiment 2}

Means of gas production profiles of the diets during $48 \mathrm{~h}$ of fermentation are presented in Figure 1, and least squares means are presented in Table 6 . As rumen fluid was collected $2 \mathrm{~h}$ after the morning feeding, it was assumed that the ruminal microorganisms were in the exponential phase of growth when rumen fluid was used for incubation. For that reason, the lag phase was

Table 5. Effects of different protein supplements on true ruminal nutrient digestibility in dual-flow continuous culture (experiment 1)

\begin{tabular}{|c|c|c|c|c|c|c|}
\hline \multirow[b]{2}{*}{$\begin{array}{l}\text { Ruminal true } \\
\text { digestibility, \% }\end{array}$} & \multicolumn{3}{|c|}{ Treatment $^{1}$} & \multirow[b]{2}{*}{ SEM } & \multicolumn{2}{|c|}{$P$-value ${ }^{2}$} \\
\hline & SBM & LCM & HCM & & $\begin{array}{c}\text { SBM vs. } \\
\mathrm{LCM}+\mathrm{HCM}\end{array}$ & LCM vs. HCM \\
\hline $\mathrm{OM}$ & 52.3 & 53.0 & 50.7 & 3.97 & 0.90 & 0.57 \\
\hline CP & 83.5 & 85.6 & 83.5 & 3.23 & 0.72 & 0.53 \\
\hline NDF & 74.1 & 76.0 & 74.5 & 3.78 & 0.80 & 0.78 \\
\hline
\end{tabular}

${ }^{1} \mathrm{SBM}=$ solvent-extracted soybean meal; LCM = low-RUP solvent-extracted canola meal (38\% RUP as a percentage of CP); HCM $=$ high-RUP solvent-extracted canola meal (50\% RUP).

${ }^{2}$ Orthogonal contrasts for effects of different protein supplements (SBM vs. LCM + HCM and LCM vs. HCM). 


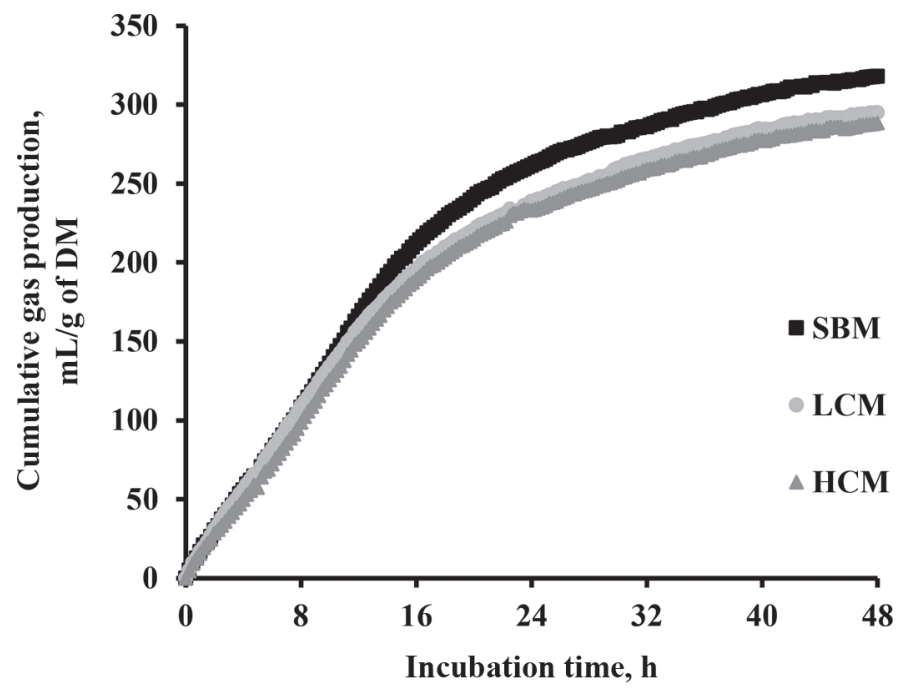

Figure 1. Ruminal gas production profiles of the diets used in experiments 1 and 2 determined with the Ankom gas production system (Ankom Technology, Macedon, NY). SBM = dietary treatment with solvent soybean meal as a protein supplement; LCM = dietary treatment with $38 \%$ RUP canola meal as a protein supplement; HCM = dietary treatment with 50\% RUP canola meal as a protein supplement.

considered as apparent (Pirt, 1975). Although diets did not differ in rate of gas production $(0.06 \mathrm{~mL} / \mathrm{h}$ average for all treatments; $P=0.56$ ), the SBM diet had a greater gas pool size (potentially fermentable fraction) than did both CM diets $(342 \mathrm{~mL} / \mathrm{g}$ of DM vs. 306 and $309 \mathrm{~mL} / \mathrm{g}$ of $\mathrm{DM}$ for SBM vs. LCM and HCM diets, respectively; $P<0.01$ ). However, $\mathrm{LCM}$ and $\mathrm{HCM}$ diets did not differ from each other $(P>0.05)$.

The greater gas pool size for the SBM diet may have been attributable to a greater OM digestibility after 48 h compared with both CM diets (Table 6). According to Ramin and Huhtanen (2013), an increase in $\mathrm{CH}_{4}$ production $(\mathrm{mol} / \mathrm{d})$ is positively correlated with diet digestibility. Another reason that could explain the greater gas pool for the SBM diet may be a greater BCVFA concentration in the SBM diet (data not shown), which may have contributed to the growth of cellulolytic and some noncellulolytic bacteria (Allison, 1969).

Dietary treatments changed total VFA concentration and acetate and butyrate molar proportions (Table 6). Total VFA concentration increased in the SBM diet compared with the CM diets, which may be explained by the greater in vitro OM digestibility observed in the SBM diet. There was an increase in butyrate and a decrease in acetate molar proportions in the SBM diet compared with the CM diets. These changes may be attributable to the conversion of acetate into butyrate, which may occur when diets high in soluble carbohydrates are fed (Demeyer, 1991). Similar results were observed in experiment 3 (Table 7 ).

Table 6. Effects of different protein supplements on in vitro gas production parameters and digestibility (experiment 2)

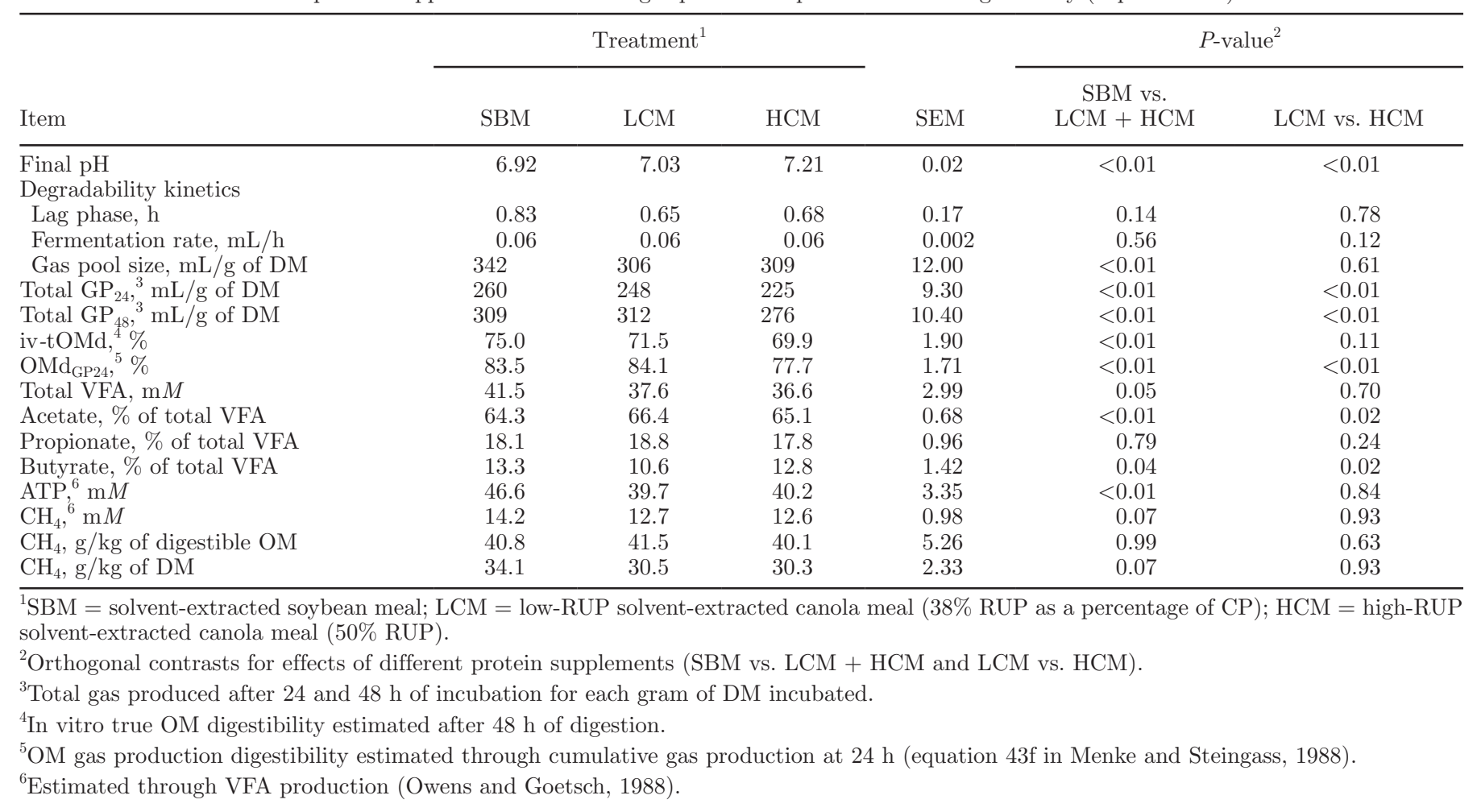


Table 7. Effects of different protein supplements on in vitro gas production parameters and digestibility (experiment 3 )

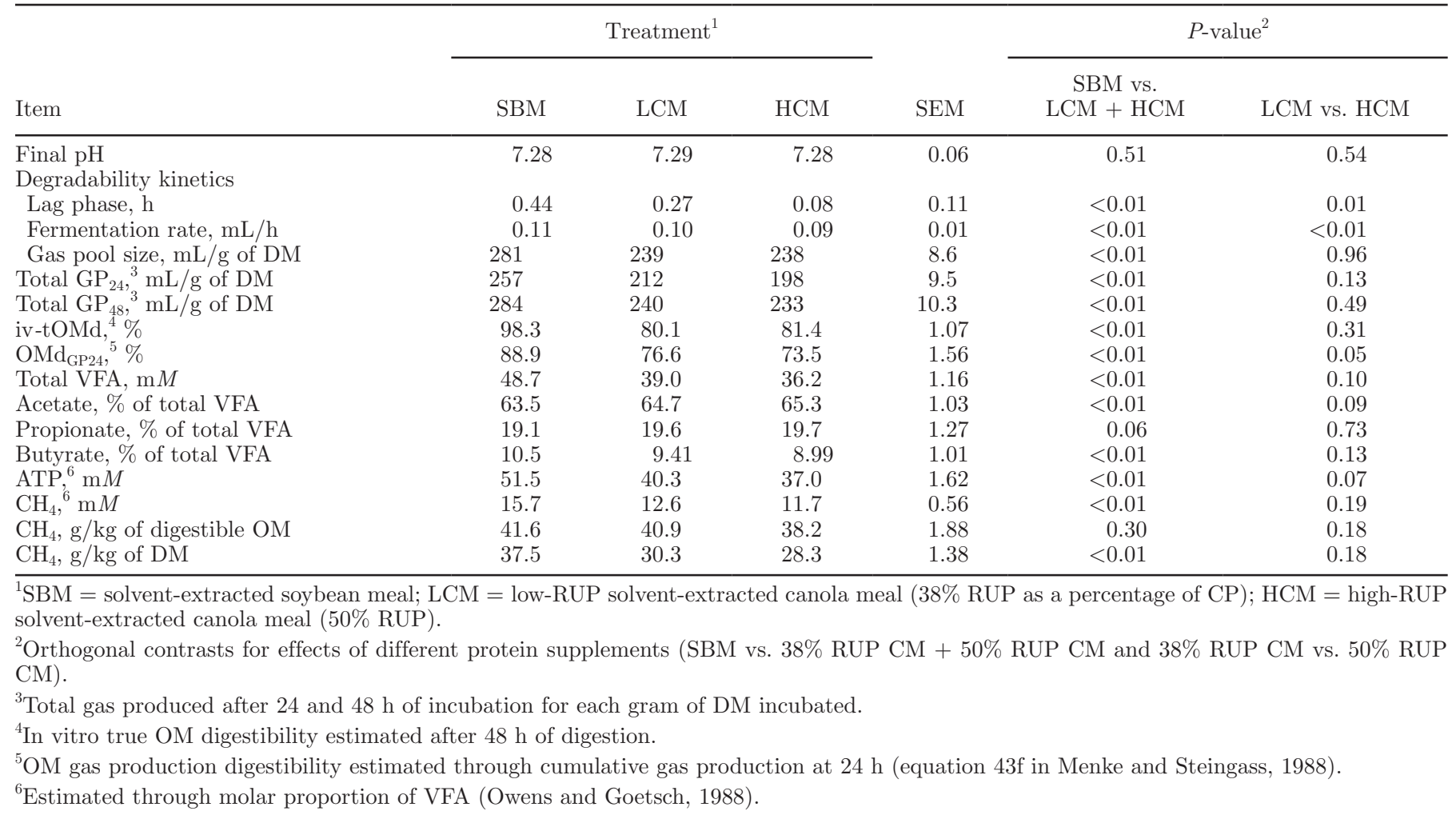

Dietary treatments affected total gas production measured over 24 and $48 \mathrm{~h}$ (Table 6 ). In the first 24 $\mathrm{h}$, the SBM diet produced more gases compared with the CM diets, probably because of greater OM digestibility as previously discussed. However, at $48 \mathrm{~h}$, when the substrate had more time for fermentation, only the HCM diet showed lower gas production $(P<0.01)$ compared with the SBM and LCM diets. These results also may be explained by $\mathrm{OM}$ digestibility, which was lower for the HCM diet than for the LCM $\operatorname{diet}(P<$ 0.01 ) after $24 \mathrm{~h}$ of digestion.

The SBM diet tended to increase $\mathrm{CH}_{4}$ production ( $\mathrm{mM}$ and $\mathrm{g} / \mathrm{kg}$ of $\mathrm{DM}$ ), which according to Owens and Goetsch (1988) may be associated with greater butyrate concentrations because for each 2 mol of butyrate produced there is a positive balance of $1 \mathrm{~mol}$ of $\mathrm{CH}_{4}$. It was also observed that BCVFA concentration was greater on the SBM diet. Our data are in accordance with Hino and Russell (1985), who observed that ruminal $\mathrm{H}_{2}$ and $\mathrm{CH}_{4}$ increase during oxidative deamination and decarboxylation of branched-chain $\mathrm{AA}$ to form BCVFA in the rumen.

The SBM diet in experiment 1 (fed every $6 \mathrm{~h}$ ) tended to result in a lower $\mathrm{pH}(P=0.10)$ than the CM diets, whereas in experiment 2 the final $\mathrm{pH}$ (after $48 \mathrm{~h}$ of fermentation) was significantly lower for the SBM diet
$(P<0.01)$. A lower $\mathrm{pH}$ may increase $\mathrm{H}_{2}$ in the medium, resulting in more ATP and $\mathrm{CH}_{4}$ production (Nelson et al., 2008). As a result, butyrate concentration tended to increase $(P=0.06)$ with the $\mathrm{pH}$ decrease on the SBM diet. When comparing $\mathrm{CH}_{4}$ production in grams per kilogram of digested OM, no differences were observed among the diets $(P>0.05)$, which indicated that $\mathrm{CH}_{4}$ production was more correlated with amount of substrate fermented than with the specific chemical composition of the diets.

\section{Experiment 3}

The main objective of experiment 3 was to evaluate ruminal gas production kinetics, in vitro OM digestibility, and $\mathrm{CH}_{4}$ production of 3 protein supplements used in experiments 1 and 2. Gas production profiles during $48 \mathrm{~h}$ of fermentation of protein supplements are presented in Figure 2, and least squares means are presented in Table 7. Lag phase in this experiment was also considered as described earlier. It was observed that SBM and 38\% RUP CM had a greater rate of gas production per hour than 50\% RUP CM (0.11, 0.10, and $0.09 \mathrm{~mL} / \mathrm{h}$, respectively; $P<0.01$ ), and SBM had greater gas pool size than both 38\% RUP CM and $50 \%$ RUP CM (281, 239, and $238 \mathrm{~mL} / \mathrm{g}$ of DM, respectively; 


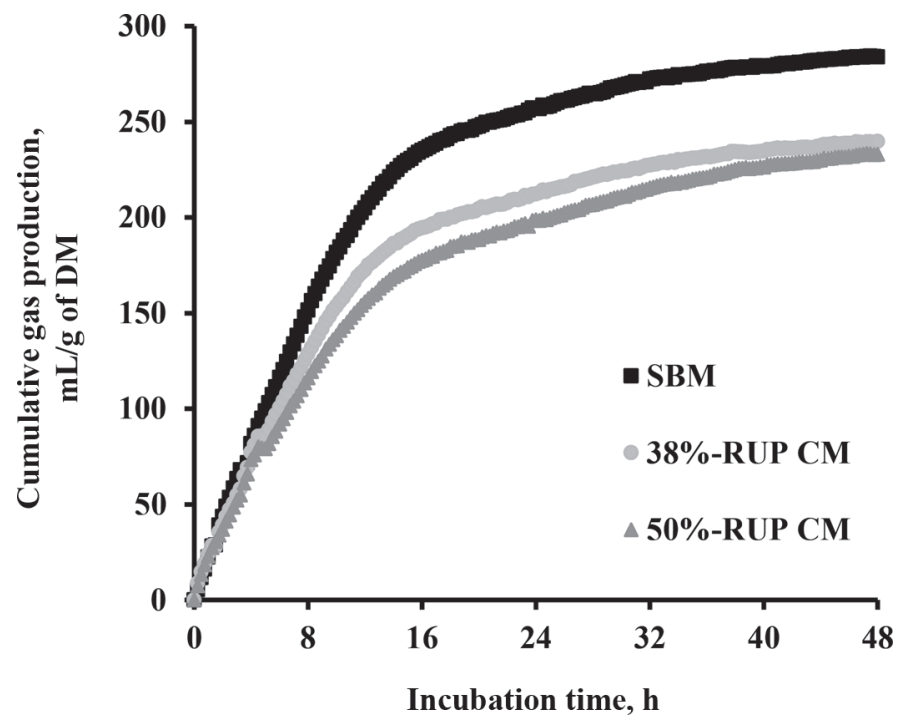

Figure 2. Ruminal gas production profiles of the 3 protein supplements (experiment 3 ). $\mathrm{SBM}=$ solvent soybean meal; $\mathrm{CM}=$ canola meal.

$P<0.01$, which reflects the greater digestibility of the SBM compared with CM ingredients evaluated in these experiments.

When the protein supplements were evaluated separately, greater $\mathrm{CH}_{4}$ production was also observed ( $\mathrm{mM}$ and $\mathrm{g} / \mathrm{kg}$ of $\mathrm{DM}$ ) for SBM compared with both $\mathrm{CM}$ diets, which may be associated with the greater OM digestibility discussed previously. The SBM supplement had a greater concentration of total VFA and tended to have a lower propionate molar proportion than both CM supplements, which may be related to greater $\mathrm{CH}_{4}$ production and total gas produced after 24 and $48 \mathrm{~h}$ of incubation for each gram of DM incubated. Another factor that could explain the greater values of $\mathrm{CH}_{4}$ and total gas production for SBM is the greater concentration of BCVFA, as discussed previously. Greater $\mathrm{CH}_{4}$ production is associated with greater energy losses and greater total gas produced after 24 and $48 \mathrm{~h}$ of incubation, which includes greenhouse gases. This may represent another advantage of CM compared with SBM and may explain why in vivo studies have shown that dietary $\mathrm{CM}$ may improve milk production when replacing SBM (Huhtanen et al., 2011; Broderick et al., 2015).

\section{CONCLUSIONS}

We hypothesized that CM with greater RUP content would change ruminal $\mathrm{N}$ metabolism compared with regular CM. The results from this study do not support the argument that changing CM RUP has an effect on ruminal $\mathrm{N}$ metabolism. It was observed that $\mathrm{CM}$ with
RUP varying from 38 up to $50 \%$ of CP did not affect ruminal $\mathrm{N}$ metabolism in a dual-flow continuous culture system. Furthermore, no major differences in ruminal N metabolism and digestibility were found between SBM and CM diets, which indicates that replacing SBM with CM has no major ruminal effects. This suggests that positive production responses previously observed when CM replaced SBM may have been attributable to postruminal effects and DMI. Minor ruminal effects observed in this study included decreasing isovalerate and BCVFA and increasing valerate molar proportions when CM replaced SBM. Despite lower $\mathrm{CH}_{4}$ production ( $\mathrm{m} M$ and $\mathrm{g} / \mathrm{kg}$ of $\mathrm{DM}$ ) for both $\mathrm{CM}$ diets compared with SBM, no differences in $\mathrm{CH}_{4} \mathrm{~g} / \mathrm{kg}$ of $\mathrm{DM}$ or $\mathrm{CH}_{4} \mathrm{~g} /$ $\mathrm{kg}$ of digestible $\mathrm{OM}$ were found among the 3 diets.

\section{ACKNOWLEDGMENTS}

The authors gratefully acknowledge the partial funding support from the Canola Council of Canada (Winnipeg, MB, Canada). They also thank the farm crew at the Main Station Field Laboratory (University of Nevada, Reno) for animal feeding and care.

\section{REFERENCES}

AFRC (Agricultural and Food Research Council). 1993. Energy and Protein Requirements of Ruminants. CAB International, Wallington, UK.

Ahvenjärvi, S., A. Vanhatalo, P. Huhtanen, and T. Varvikko. 1999 Effects of supplementation of a grass silage and barley diet with urea, rapeseed meal and heat-moisture-treated rapeseed cake on omasal digesta flow and milk production in lactating dairy cows. Acta Agric. Scand. A 49:179-189.

Allison, M. J. 1969. Biosynthesis of amino acids by ruminal microorganisms. J. Anim. Sci. 29:797-807.

Allison, M. J.,, and M. P. Bryant. 1963. Biosynthesis of branchedchain amino acids from branched-chain fatty acids by rumen bacteria. Arch. Biochm. Biophys. 101:269-277.

AOAC (Association of Official Analytical Chemists). 1990. Official Methods of Analysis. 15th ed. AOAC, Arlington, VA.

AOAC International. 2005. Official Methods of Analysis. 18th ed. AOAC International, Arlington, VA.

Bach, A., S. Calsamiglia, and M. D. Stern. 2005. Nitrogen metabolism in the rumen. J. Dairy Sci. 88(E Suppl. 1):E9-E21.

Bach, A., M. Ruiz Moreno, M. Thrune, and M. D. Stern. 2008. Evaluation of the fermentation dynamics of soluble crude protein from three protein sources in continuous culture fermenters. J. Anim. Sci. 86:1364-1371.

Bach, A., and M. D. Stern. 1999. Effects of different levels of methionine and ruminally undegradable protein on the amino acid profile of effluent from continuous culture fermenters. J. Anim. Sci. 77:3377-3384.

Benedeti, P. D. B., L. G. da Silva, E. M. de Paula, T. Shenkoru, M. I. Marcondes, H. F. Monteiro, B. Amorati, Y. Yeh, S. R. Poulson, and A. P. Faciola. 2015. Effects of partial replacement of corn with glycerin on ruminal fermentation in a dual-flow continuous culture system. PLoS ONE 10:e0143201.

Brito, A. F., and G. A. Broderick. 2007. Effects of different protein supplements on milk production and nutrient utilization in lactating dairy cows. J. Dairy Sci. 90:1816-1827.

Brito, A. F., G. A. Broderick, and S. M. Reynal. 2007. Effects of different protein supplements on omasal nutrient flow and microbial 
protein synthesis in lactating dairy cows. J. Dairy Sci. 90:1828 1841.

Broderick, G. A., S. Colombini, S. Costa, M. A. Karsli, and A. P. Faciola. 2016. Chemical and ruminal in vitro evaluation of Canadian canola meals produced over 4 years. J. Dairy Sci. 99:7956-7970.

Broderick, G. A., A. P. Faciola, and L. E. Armentano. 2015. Replacing dietary soybean meal with canola meal improves production and efficiency of lactating dairy cows. J. Dairy Sci. 98:5672-5687.

Broderick, G. A., R. J. Wallace, and E. R. Orskov. 1991. Control of rate and extent of protein degradation. Pages 541-592 in Physiological Aspects of Digestion and Metabolism in Ruminants. T. Tsuda, Y. Sasaki, and R. Kawashima, ed. Academic Press, San Diego, CA.

Calsamiglia, S., M. D. Stern, and J. L. Firkins. 1996. Comparison of nitrogen-15 and purines as microbial markers in continuous culture. J. Anim. Sci. 74:1375-1381.

Canola Council of Canada. 2015. Canola Meal Feeding Industry Guide. 5th ed. Canola Council of Canada, Winnipeg, MB, Canada.

Chaney, A. L., and E. P. Marbach. 1962. Modified reagents for determination of urea and ammonia. Clin. Chem. 8:130-132.

Demeyer, D. 1991. Quantitative aspects of microbial metabolism in the rumen and hindgut. Pages 217-237 in Rumen Microbial Metabolism and Ruminant Digestion. J. P. Jouany ed. INRA Editions, Paris, France.

Gidlund, H., M. Hetta, S. Krizsan, S. Lemosquet, and P. Huhtanen 2015. Effects of soybean meal or canola meal on milk production and methane emissions in lactating dairy cows fed grass silagebased diets. J. Dairy Sci. 98:8093-8106.

Hedqvist, H., and P. Udén. 2006. Measurement of soluble protein degradation in the rumen. Anim. Feed Sci. Technol. 126:1-21.

Hino, T., and J. B. Russell. 1985. Effect of reducing-equivalent disposal and $\mathrm{NADH} / \mathrm{NAD}$ on deamination of amino acids by intact rumen microorganisms and their cell extracts. Appl. Environ. Microbiol. 50:1368-1374.

Hoover, W. H., B. A. Crooker, and C. J. Sniffen. 1976. Effects of differential solid-liquid removal rates on protozoa numbers in continuous cultures of rumen contents. J. Anim. Sci. 43:528-534.

Huhtanen, P., M. Hetta, and C. Swensson. 2011. Evaluation of canola meal as a protein supplement for dairy cows: A review and a metaanalysis. Can. J. Anim. Sci. 91:529-543.

Institut national de la recherche agronomique (INRA). 2007. Nutrition of Cattle, Sheep and Goats: Animal Needs-Values of Feeds. Éditions Quae, Versailles, France.

Martineau, R., D. R. Ouellet, and H. Lapierre. 2013. Feeding canola meal to dairy cows: A meta-analysis on lactational responses. J. Dairy Sci. 96:1701-1714.

Maxin, G., D. R. Ouellet, and H. Lapierre. 2013. Effect of substitution of soybean meal by canola meal or distillers grains in dairy rations on amino acid and glucose availability. J. Dairy Sci. 96:7806-7817.

Menke, K. H., and H. Steingass. 1988. Estimation of the energetic feed value obtained from chemical analysis and in vitro gas production using rumen fluid. Anim. Res. Develop. 28:7-55.

Mertens, D. R. 2002. Gravimetric determination of amylase-treated neutral detergent fiber in feeds with refluxing in beakers or crucibles: Collaborative study. J. AOAC Int. 85:1217-1240.
Nelson, D. L., A. L. Lehninger, and M. M. Cox. 2008. Lehninger Principles of Biochemistry. 5th ed. Macmillan, London, UK.

National Research Council (NRC). 2001. Nutrient Requirements of Dairy Cattle. 7th rev. ed. National Academies Press, Washington, DC.

Owens, F., and A. Goetsch. 1988. Ruminal fermentation. Pages 145171 in The Ruminant Animal. Digestive Physiology and Nutrition. D. C. Church, ed. Prentice-Hall, Englewood Cliffs, NJ.

Paula, E. M., M. A. C. Danes, N. E. Lobos, F. L. Drago, G. I. Zanton, G. A. Broderick, and A. P. Faciola. 2016a. Effects of replacing soybean meal with canola meal or treated canola meal on ruminal digestion, and omasal nutrient flow in lactating dairy cows. J. Dairy Sci. 99(E-Suppl. 1):668-669. (Abstr.)

Paula, E. M., M. A. C. Danes, N. E. Lobos, G. I. Zanton, G. A. Broderick, and A. P. Faciola. 2016b. Effects of replacing soybean meal with canola meal or treated canola meal on nitrogen metabolism and total tract digestibility in lactating dairy cows. J. Dairy Sci 99(E-Suppl. 1):757-758. (Abstr.)

Pirt, S. J. 1975. Principles of Microbe and Cell Cultivation. Blackwell Scientific, Hoboken, N.J.

Ramin, M., and P. Huhtanen. 2013. Development of equations for predicting methane emissions from ruminants. J. Dairy Sci. 96:24762493

Reynal, S. M., and G. A. Broderick. 2005. Effect of dietary level of rumen-degraded protein on production and nitrogen metabolism in lactating dairy cows. J. Dairy Sci. 88:4045-4064.

Reynal, S. M., I. R. Ipharraguerre, M. Lineiro, A. F. Brito, G. A Broderick, and J. H. Clark. 2007. Omasal flow of soluble proteins, peptides, and free amino acids in dairy cows fed diets supplemented with proteins of varying ruminal degradabilities. J. Dairy Sci. 90:1887-1903.

Sanchez, J. M., and D. W. Claypool. 1983. Canola meal as a protein supplement in dairy rations. J. Dairy Sci. 66:80-85.

SAS Institute. 2002. SAS User's Guide for Windows Environment 9.0. SAS Institute, Cary, NC.

Silva, L. G., J. Bunkers, E. M. Paula, T. Shenkoru, Y. Yeh, B. Amorati, D. Holcombe, and A. P. Faciola. 2016. Effects of flaxseed and chia seed on ruminal fermentation, nutrient digestibility, and longchain fatty acid flow in a dual-flow continuous culture system. J Anim. Sci. 94:1600-1609.

Tagliapietra, F., M. Cattani, H. H. Hansen, I. K. Hindrichsen, L. Bailoni, and S. Schiavon. 2011. Metabolizable energy content of feeds based on 24 or $48 \mathrm{~h}$ in situ NDF digestibility and on in vitro $24 \mathrm{~h}$ gas production methods. Anim. Feed Sci. Technol. 170:182-191.

Van Soest, P. J., and R. McQueen. 1973. The chemistry and estimation of fibre. Proc. Nutr. Soc. 32:123-130.

Weller, R. A., and A. F. Pilgrim. 1974. Passage of protozoa and volatile fatty acids from the rumen of the sheep and from a continuous in vitro fermentation system. Br. J. Nutr. 32:341-351.

Werner, R. A., B. A. Bruch, and W. A. Brand. 1999. Conflo III-An interface for high precision delta ${ }^{13} \mathrm{C}$ and $\operatorname{delta}^{15} \mathrm{~N}$ analysis with an extended dynamic range. Rapid Commun. Mass Spectrom. $13: 1237-1241$ 